\title{
The Effects of Sewage Water on Ultrastructure of Chlorella vulgaris and Scenedesmus quadricauda
}

\author{
Hanan A. Said * and Rabea A. Shehab ** \\ * Botany Department, Faculty of Science, Fayoum University \\ ** Biological and Geological Sciences Depart., Faculty of Education, Ain Shams \\ University.
}

\begin{abstract}
:
The present work was carried out to study the effect of heavy metals from Collection station Mostorod Greater Cairo Egypt in Chlorella vulgaris and Scenedesmus quadricauda on amino acids content and ultrastructure. Results obtained revealed that the content of amino acids was increased gradually at all different concentrations of heavy metals $(25 \%, 50 \%, 75 \%$ and $100 \%)$ compared to control. Cellular damage was studied by transmission electron microscope. It was observed that Chlorella vulgaris and Scenedesmus quadricauda when exposed to different concentrations of heavy metals revealed drastic changes in the overall ultrastructure such as the chloroplast separated far from the wall, the lamelly of the chloroplast appeared to be separated from each other, the pyrenoid disappeared and electro dense granular bodies identified as polyphosphate granules, appeared apparently in the cells. Damage to the algae ultrastructure was more severe with elevated heavy metal concentrations. These responses of Chlorella vulgaris and Scenedesmus quadricauda indicated their tolerance of heavy metal stress.
\end{abstract}

Key words: Chlorella, Scenedesmus, Heavy metals, Amino acids, Ultrastructure.

\section{Introduction}

Pollution phenomenon, coming from the organic and inorganic substances which are released into the environment as a result of domestic, agricultural and industrial water activities lead to organic and inorganic pollution (Lim et al., 2010; Muhammad et al., 2018) High concentrations of essential metals can be toxic to living organism because of non-biodegradability, bioaccumulation and persistence in nature (Pahlavanzadeha et al., 2010; Anbalagan and Sivakami, 2018). Using microorganisms as biosorbent, offers alternative method to conventional processing methods, because of their strong metal binding capacity, low cost, high efficiency in dilute effluents and environment friendliness (Philips et al., 2003; Gupta and Rastogi, 2008;Zhang et al., 2013). Algae are ideal for 
the reducing and removal the concentration of heavy metals due to high biosorption capacity, high tolerance to heavy metals, large surface area/ volume ratios, ability to grow autotrophically and heterotrophically and phytochelatin production (Chekroun and Baghour, 2003).

Heavy metal ions could interrupt metabolic processes by competing for the protein binding sites; activate enzymes and various biological reactive groups, causing poor or no growth. Heavy metal ions (such as $\mathrm{Pb}^{2+}$ ) are capable of binding to thylakoid membrane causing the alteration of the ultrastructure of thylakoids, which deteriorate the function of thylakoids and some reports in the destruction of the chloroplast of heavy metal ions at higher concentrations are reported by (Heng et al., 2004; Lamaia et al., 2005). A chain of metabolic events such as the photosynthesis and respiration and continuing with uptake and assimilation of nutrients, dilution of intracellular level of the heavy metal ions, etc. play an important role in balancing the cellular homeostasis (Tripathi and Gaur, 2006).

Amino acids are essential in the synthesis of proteins and in the formation of secondary metabolism molecule, participate in cell signaling, protein phosphorylation, synthesis of hormones, antioxidant capacity, gene expression and homeostasis regulation and in various physiological processes (Cuin and Shabala, 2007; Pérez-Urria and García, 2009; Wu, 2009).

Heavy metal resistance in microalgae may result from (i) the ability to prevent uptake (avoidance) by adsorption of toxic metal ions to cell-associated materials and/or cell wall components (De Philippis and Micheletti, 2009; Naja and Volesky, 2011) or secretion of metal-binding organic compounds to the surrounding environment. (ii) the ability to cope with high amounts of heavy metals inside tissues (tolerance), an active process that involves the uptake (absorption) and accumulation of the metal ions inside the cell (Levy et al., 2008).

Inside the cell, heavy metal detoxification may be achieved by binding to specific intracellular compounds to formation of metal-binding peptides or proteins such as metallothioneins (Hassinen et al., 2011) and phytochelatins and Gluthione (GSH) (Hirata et al., 2005). Organic acids i.e., malic, carboxylic, oxalic, amino acids like nicotinamine, histidine, and some phosphate derivatives are the ligands for heavy metals and are found to play a role in detoxification and tolerance. Where, the exclusion of toxic heavy metals from cells by ion- selective 
metal transporters, and excretion or compartmentalization were reported by (Hu et al., 2004; Gasic and Korban, 2006; Perales-Vela et al., 2006). Also, polyphosphate bodies enable the fresh water algae to store and sequestered heavy metals within the cell. Polyphosphate bodies have two functions in algae, act as a detoxification mechanism and provide a storage pool for the heavy metals (Dwivedi, 2012). But polyphosphate granules have the ability to bind to many different metals (Colico et al., 2010). The aim of the present work was to study the effect of heavy metals in Chlorella vulgaris and Scenedesmus quadricauda on amino acids content and ultrastructure.

\section{Materials and Methods}

\section{Collection and Preparation of Samples:}

Wastewater samples were collected from collection station Mostorod Greater Cairo Egypt once during Winter (January, Daytime) 2015, they were stored in cleaned stoppered plastic bottles and refrigerated in deep-freezer at -20 ${ }^{\mathrm{O}} \mathrm{C}$ and analyzed within few hours after arrival to the Laboratory. Physical and some chemical parameters were measured in station during the sample collection Table (1).

\section{Organism and culture Methods}

Two pure algal strains (Chlorella vulgaris and Scenedesmus quadricauda) have been provided by Prof. Dr/ Gamila Hussein Ali Professor of Phycology, Water Pollution Department, National Research Centre, Egypt. The best growth conditions were at the 12days, 4000 Lux light intensity $\mathrm{pH} 7$ at $\left(22^{\circ} \pm 1\right)$ using BG-II 11 media (Stanier et al., 1971). 
Table (1):Physical and chemical parameters of water sample collected at Mostorod plant.

\begin{tabular}{|l|c|}
\hline \multicolumn{1}{|c|}{ Parameters } & Concentration \\
\hline pH & 7.3 \\
\hline Electric Conductivity $\left(\mathbf{d s m}^{-1}\right)$ & 2.04 \\
\hline Calcium (meq /L) & $\mathbf{2}$ \\
\hline Magnesium (meq /L) & 0.8 \\
\hline Sodium (meq/L) & $\mathbf{5 . 7 7}$ \\
\hline Potassium (meq/L) & $\mathbf{0 . 7}$ \\
\hline Carbonate (meq/L) & - \\
\hline Bicarbonate (meq/L) & $\mathbf{3}$ \\
\hline Chloride (meq/L) & $\mathbf{1 . 5}$ \\
\hline Sulfate (meq /L) & $\mathbf{4 . 7 7}$ \\
\hline Copper (mg/L) & $\mathbf{0 . 0 4 8}$ \\
\hline Zinc (mg/L) & $\mathbf{0 . 1 8 1}$ \\
\hline Manganese (mg/L) & $\mathbf{0 . 1 1 6}$ \\
\hline Iron (mg/L) & $\mathbf{0 . 4 6 6}$ \\
\hline Lead (mg/L) & $\mathbf{0 . 2 8 2}$ \\
\hline Aluminum* (mg/L) & $\mathbf{0 . 1 9 6}$ \\
\hline Barium** (mg/L) & $\mathbf{0 . 0 5 4}$ \\
\hline *Aluminumis the third most abundant element after oxygen and silicon and is a light metal;*Barium is the $16^{\text {th }}$
\end{tabular}

most abundant non- gaseous element of the Earth's crust (metallic alkalinity earth metal).

\section{Treatment}

Different concentrations of wastewater contain copper, zinc, manganese, iron; lead, aluminum and barium in four concentrations of heavy metals in combination were used $(25 \%, 50 \%, 75 \%$ and $100 \%)(\mathrm{v} / \mathrm{v}$ sterile culture medium BG-II / wastewater) total volume of $500 \mathrm{ml}$ in $1000 \mathrm{ml}$ Erlenmeyer flasks. In 50 $\mathrm{ml}$ of the dilute growth cultures of Chlorella vulgaris and Scenedesmus quadricauda were transformed to $450 \mathrm{ml}$ of the sterile culture medium BG-II in $1000 \mathrm{ml}$ Erlenmeyer flasks. Control samples contained $500 \mathrm{ml}$ of sterile culture medium BG-II only without wastewater. All treatments and control samples in triplicates were incubated at room temperature $\left(22^{\circ} \pm 1\right)$ under continuous illumination (4000 lux) with a daily light dark cycle of 14-10 hrs for a period of 12 days. 
Amino acids content were determined according to the method of (Bailey, 1967) using amino acid analyzer.

\section{Electron microscopy}

The preparation of algal cell for transmission electron microscope was carried out according to the method of (Reynolds, 1963). The sections were then examined, photographed by a JEOL 1200 EXII transmission electron microscope.

\section{Results and Discussion}

It well known that algal cells exposed to heavy metals may suffer serious morphological and physiological alterations to algal cells and the stimulatory and inhibitory effects of heavy metals depend on concentration. However, mechanism of pollutant action can be described by two fundamental actions on growth processes and photosynthesis, (Visviki and Rachlin, 1994; Rocchetta et al., 2006; Afkar et al., 2010).

Plants synthesized a set of diverse metabolites when exposed to metals such as amino acids (proline and histidine), peptides (phytochelatin and glutathione) so the metabolism of nitrogen is central to the plant response to heavy metals. Also, amino acids are ligands for heavy metals and are found to play important role in detoxification and tolerance (Chekroun and Baghour, 2003).

It was observed from the present study Table (2) that treatment with the low and moderate concentrations of heavy metals $(25 \%, 50 \%$ and $75 \%)$ did not cause any effect in number of amino acids but treatment with the highest concentrations of heavy metals $(100 \%)$ caused decrease in the number of amino acids in Chlorella vulgaris as compared with control. On the other hand, Scenedesmus quadricauda treatment with the lower concentrations of heavy metals (25\% and 50\%) cause increase in the number of amino acids and treatment with the highest concentrations of heavy metals $(75 \%$ and $100 \%)$ have no effect in the number of amino acids as compared with control. The present results agree with those observed by Omar (2002), who found that zinc at low concentrations 


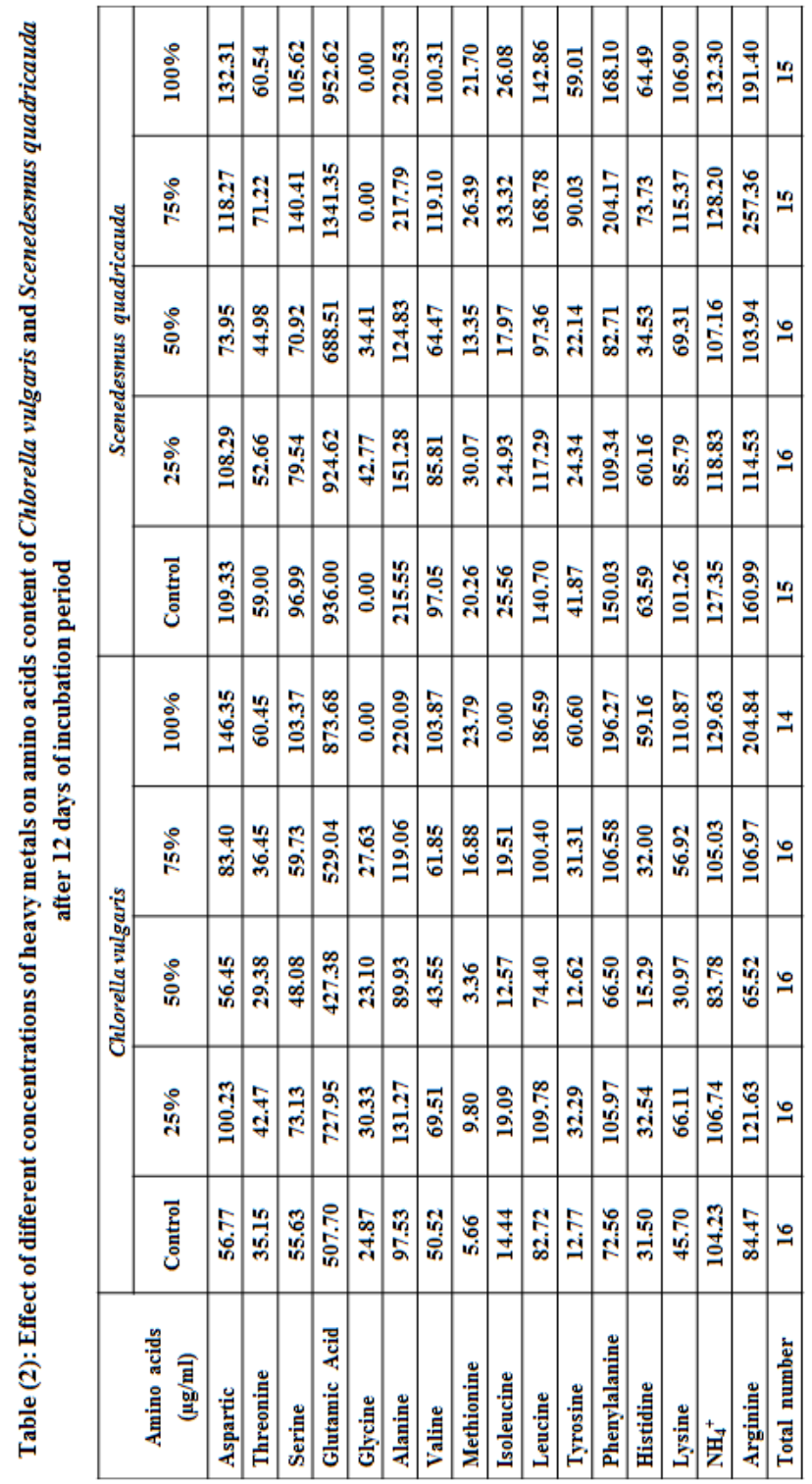


increased total amino acid contents, however, decreased it at high concentrations. The amino acids accumulation in response to metals concentrations may lead to the assumption that suppressed protein biosynthesis encouraged accumulation of free amino acids, or may lead to some counteracting chelating mechanism against the toxicity of heavy metals (El-Sheekh et al., 2003; Osman et al., 2004; Fathi et al., 2005).

Glutathione forms complexes with heavy metals and as a response to heavy metals stress, so plants inducted glutathione and synthesis of cysteine. Glycinehas a role in glutathione synthesis so the amount of glycine decreased in heavy metal stress (Arya et al., 2008). Glutamic acid and glycine participate in glutathione synthesis increasing the antioxidant capacity of the plant (Wu, 2009 and Akram et al., 2011). This accordance with present data that absence of glycine in concentration $100 \%$ in Chlorella vulgaris and in control, concentrations $75 \%$ and $100 \%$ in the case of Scenedesmus quadricauda. Isoleucine was absent in concentration $100 \%$ in Chlorella vulgaris because synthesis of isoleucine decreased due to their synthesis and catabolism influence by different developmental and environmental conditions which go with the line of (Joshi $\boldsymbol{e t}$ al., 2010).

Abdel Latef and Sallam (2015) recorded that in maize wastewater irrigation improved the accumulation of total free amino acids content. Also, Homer et al. (1997) observed amino acids accumulation in response to heavy metals pollution in three hyper accumulator species, Phyllanthus palwanensis, Walsura monophylla, and Dechampetalum geloniodes this is similar to present results.

The free amino acids accumulation in plants under stress have important roles in metal toxicity tolerance through detoxifying heavy metals, regulating intracellular $\mathrm{pH}$ and ion transport and scavenging the reactive oxygen species (Rai, 2002). Miflin and Habash (2002) reported that plants evolved some enzymes to cope with stress that convert amino acids, keto-acids, and amides to be used as carbon source when carbon deficiency becomes a limiting factor for development and growth. Total free amino acids concentration increased in broad bean plants under copper treatment and this increase indicating the role of amino acids in metal chelation (Hall, 2002; Xiong et al., 2006; Azooz et al., 2012). 
Results of detailed TEM examinations of both algal species, were illustrated in Figures (1-10) which showed the effects of different concentrations of heavy metals $(25 \%, 50 \%, 75 \%$ and $100 \%)$ as well as the control on cell ultrastructure of Chlorella vulgaris and Scenedesmus quadricauda.

Chlorella vulgaris at control condition figure (1 A-C) showed that it was characterized by spherical cells, a smooth cell wall and a parietal chloroplast. Chlorella vulgaris at control condition figure $(\mathbf{1} \mathbf{A}-\mathbf{C})$ showed that it was characterized by spherical cells, a smooth cell wall and a parietal chloroplast. The ultrastructure of Chlorella vulgaris at concentrations 25\%, 50\%, 75\% and $100 \%$ was illustrated in Figures ( 2 - 5). It is clear from these figures that:

-The rigged wall clearly appeared and the chloroplast separated far from the wall in (Figure (2 A, C, D); Figure (3 A, C, D); Figure (4A-E) and Figure (5B, C).

- The lamellae of the chloroplast appeared to be separated from each other in (Figure (2 A-E); Figure (3 A-G); Figure (4 A-E) and Figure (5 A-D) and the pyrenoid disappeared in Figure (3 A, C, D, F); Figure (4 C, D, E) and Figure (5 B, C, D).

- Electrodense granular bodies identified as polyphosphate granules, appeared apparently in the cells in (Figure ( 2 B, C, D, E), Figure (3 A-G), Figure (4 A-E) and Figure (17 A-D).

- Dark electron dense layer in the cell envelop appeared in (Figure 3D); Figure (4 A, C, E) and Figure (5 A, C).

The studied metals influenced Chlorella vulgaris and Scenedesmus quadricauda cells with the greatest ultrastructure change caused by high concentrations of heavy metals. Present data showed dark amorphous electron dense layer appeared in the cell envelop of cells after treated with heavy metals this is reflect the external surface sorption which is considered as the first defense mechanism to limit heavy metals toxicity (Macfie et al., 1994; Tuzun et al., 2005).Swift and Forciniti (1997) reported that once external sorption reaches the saturated stage, internal uptake begins in Anabaena cylindrica so lead phosphate was precipitated on the cell wall and then inside the cell. The differences in 
subcellular effects induced by $\mathrm{Cu}, \mathrm{Zn}$ and $\mathrm{Cd}$ are probably due to specific adaptation mechanisms developed by Chlorella vulgaris.

Chlorella vulgaris and Scenedesmus quadricada cells showed an alteration in ultrastructural of the organization and shape of thylakoids that confirm a damage of the photosynthetic apparatus. Chloroplasts and their arrangement represent a primary target of toxic substances in algae and higher plants.

The alternation in shape of chloroplast could be a consequence of a perturbation of cation exchange induced by heavy metal treatment while the alterations in structure of the thylakoid system could depend on heavy metals ability to bind to proteins and to interfere with their normal functions also oxidative damage induction (Nacorda et al., 2007; Basile et al., 2008). The accumulation of ROS, peroxides and free radical lead to lipid peroxidation, altered ultrastructure of chloroplast and distortion of thylakoid membranes (Sharma and Dubey, 2005; Islam et al., 2008; Basile et al., 2012).

Mitochondria are a common target of the heavy metal in freshwater green algae. From this study the starch granule increases in size due to the rapid mitochondria deterioration caused accumulation of starch grains that cells might act as energy reserve to the cell after the deterioration of organelles especially mitochondria, chloroplast, and pyrenoid. Consequently, since the respiratory activities cannot be carried out without mitochondria, accumulation of starch results in the disarrangement of the chloroplasts, as is reported by (Wong $\boldsymbol{e t}$ al., 1994; Miao and Wang, 2006) which agree with the present investigation.

Also, lead caused distortion of ultrastructure of chloroplast with compact grana, disrupted thylakoid membranes and small starch grains in Vignaungui culata (Kasim et al., 2014) this agreement with our results because sewage has high amount of lead $(0.282 \mathrm{mg} / \mathrm{L})$. 
While, Scenedesmus quadricauda was characterized at control condition by: colony containing of 2-4-8 oblong- cylindrical cells usually in one series. Outer cells with a long curved spine at each pole; inner cells without spines and a parietal chloroplast (Figure 6).

The ultrastructure of Scenedesmus quadricauda at concentrations of 25\%, $50 \%, 75 \%$ and $100 \%$ was showed in figures (7- 10). It is clear from these figures that:

-Significant increase was observed in the cell wall of Scenedesmus quadricauda in (Figure (7 D, E); Figure (8 A, H); Figure (9 A, B, C, F) and Figure (10 A, B, C, F, G, H, I).

- A clear separation of the chloroplast lamellae in (Figure (7 D); Figure 8 C, D, E, F, G, H); Figure (9 A, B, C, E, F) and Figure (10 A, B, C, E, G, H) where, the pyrenoid disappeared in (Figure $(9$ A, C, D); Figure $(8 \mathbf{A}, \mathbf{F})$ Figure (9 A-F) and Figure (10 A-I).

-The number of starch granules increased largely, but with a reduced size in (Figure (7 A, B, C); Figure (8 A, F, G, H, I); Figure (9 B, C, D, E) and Figure $(10 \mathrm{~B}, \mathrm{D}, \mathrm{E}, \mathrm{F}, \mathrm{I})$.

-Spherical electron dense bodies were noticed within the cells in (Figure (7 A-E); Figure (8 A, B, C, F, G, H, I); Figure (9 B, C, D, E, F) and Figure (10 B, D, E, F, G, I).

- Gradual disappearance of the nuclear membrane in Figure (8 C, D, G, H, I) Figure (9 A) and Figure (10 E, F).

Our obtained data recorded spherical electron dense bodies bioaccumulation inside Chlorella vulgaris and Scenedesmus quadricauda cells that coincided with similar granules observed in different heavy metal treated microalgae reported in Pseudochlorococcum typicum by (Aguilera and Amils, 2005). The deposition of metal inside the cytoplasm or vacuoles was a mechanism contributed to the tolerance of heavy metal by minimizing as possible the cytoplasmic metal concentrations by complexing or binding the metal ions with phytochelatin or in the form of metallo-iron, metallo-sulfur or metallo-phosphate 
complexes in the cytosol and carrying them into the vacuoles where the acidic $\mathrm{pH}$ displace the metal, allowing the peptide to return to the cytosol. In the vacuole, organic acids usually present in highconcentration which sequestered by metals. Perales-vela et al. (2006) and Shanab et al. (2012) reported that this performed as detoxification mechanisms or a cellular protection. Also, Rachlin et al. (1984) and Kahoko et al. (2003) recorded that electron dense deposits were from polyphosphate bodies. Polyphosphate bodies have the ability to protect algal cells from metal toxicity and also to accumulate metals.

The number of vacuoles increased in Chlorella vulgaris due to heavy metal stress this is related to vacuolation could contribute to compartmentalization of toxic metals (Crang and Jensen 1975). Niskikawa et al. (2003) reported that the number of vacuoles increased as well as the presence of electron dense deposits in membrane whorls and vacuole was detected in Chlamydomonas acidophila treated by $\mathrm{Zn}, \mathrm{Cd}$ and $\mathrm{Cu}$. 


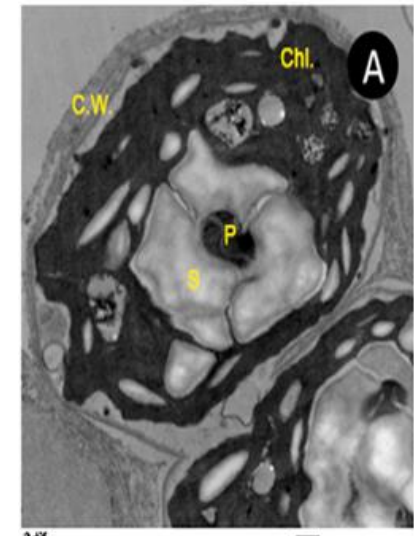

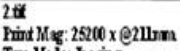

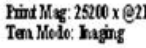
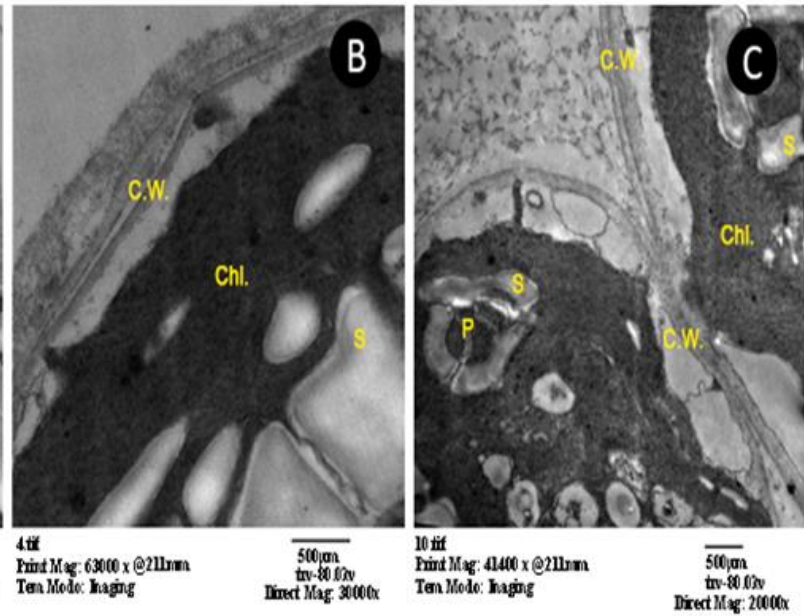

Figure (1 A-C): Ultrastructure of Chlorella vulgaris at Control Condition Abbreviations: Chl.: Chloroplast; C.W.: Cell wall; P: Pyrenoid; S: Starch

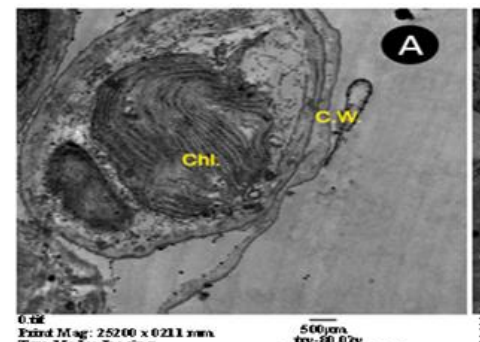

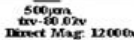

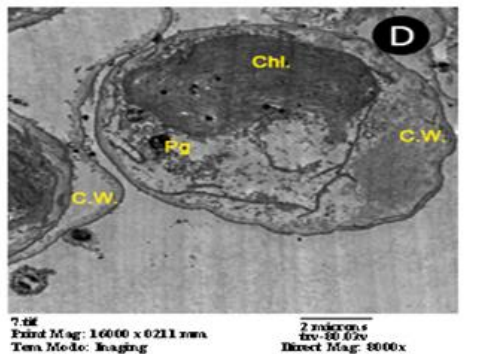

Figure (2 A-E): Ultrastructure of Chlorella vulgaris Treated with (25\%) Sewage Concentration Abbreviations: Chl.: Chloroplast; C.W.: Cell wall; Pg: Polyphosphate granules

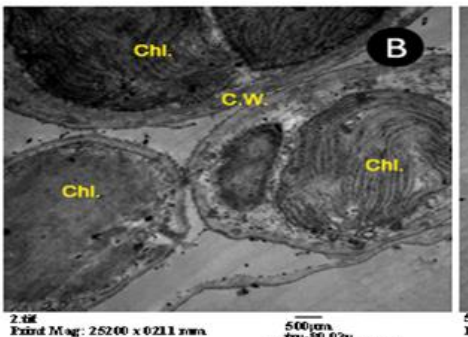

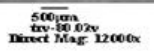
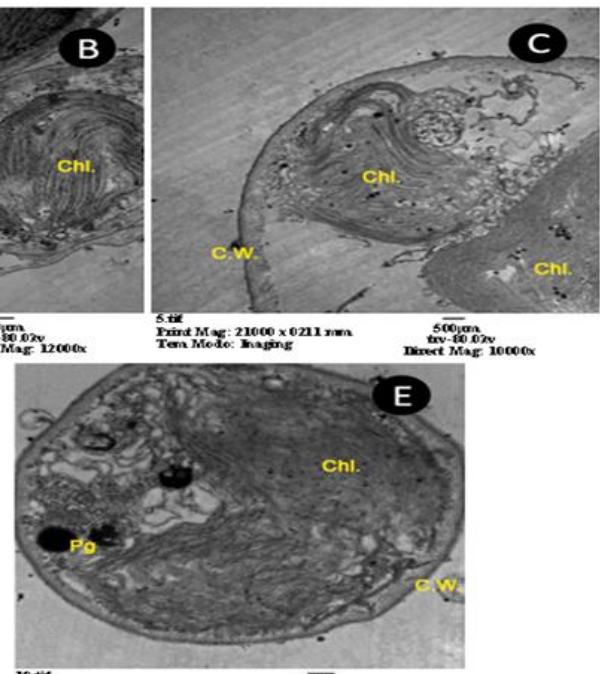

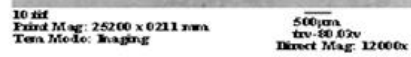

- 34 - 

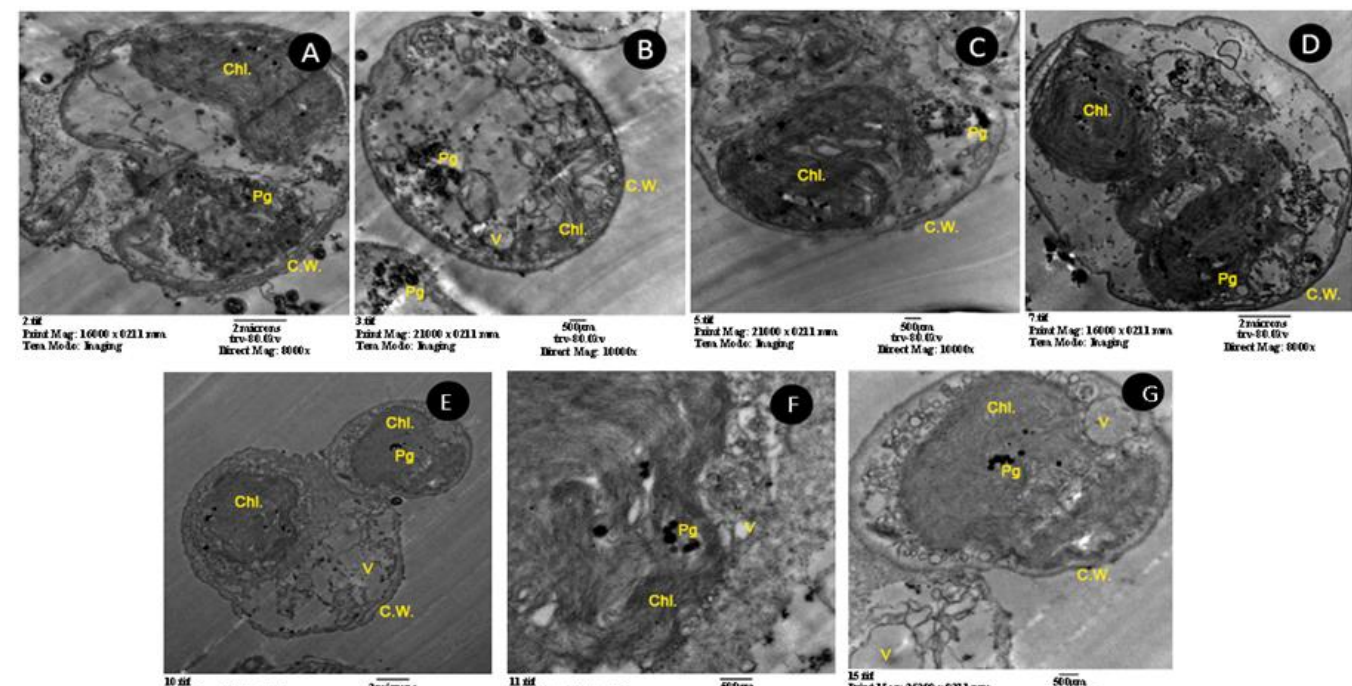

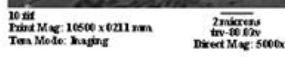
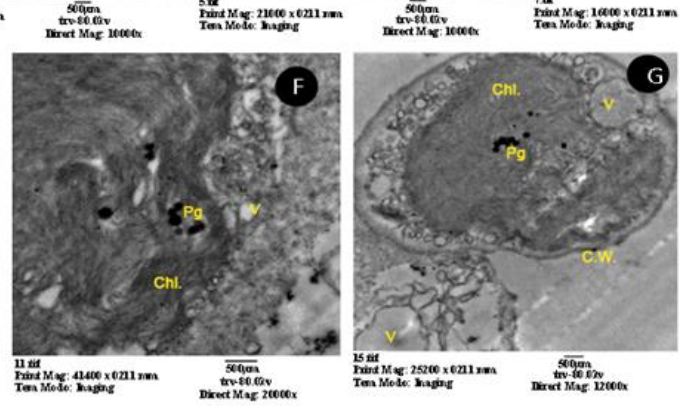

Figure (3 A-G): Ultrastructure of Chlorella vulgaris Treated with (50\%) Sewage Concentration

Abbreviations: Chl.: Chloroplast; C.W.: Cell wall; Pg: Polyphosphate granules; V: Vacuole
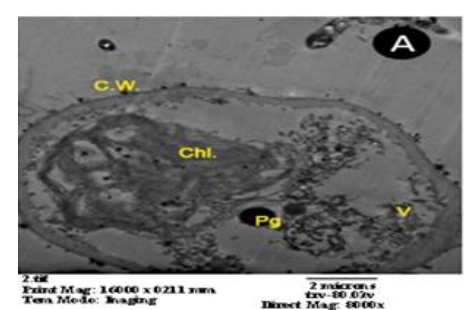

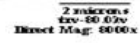
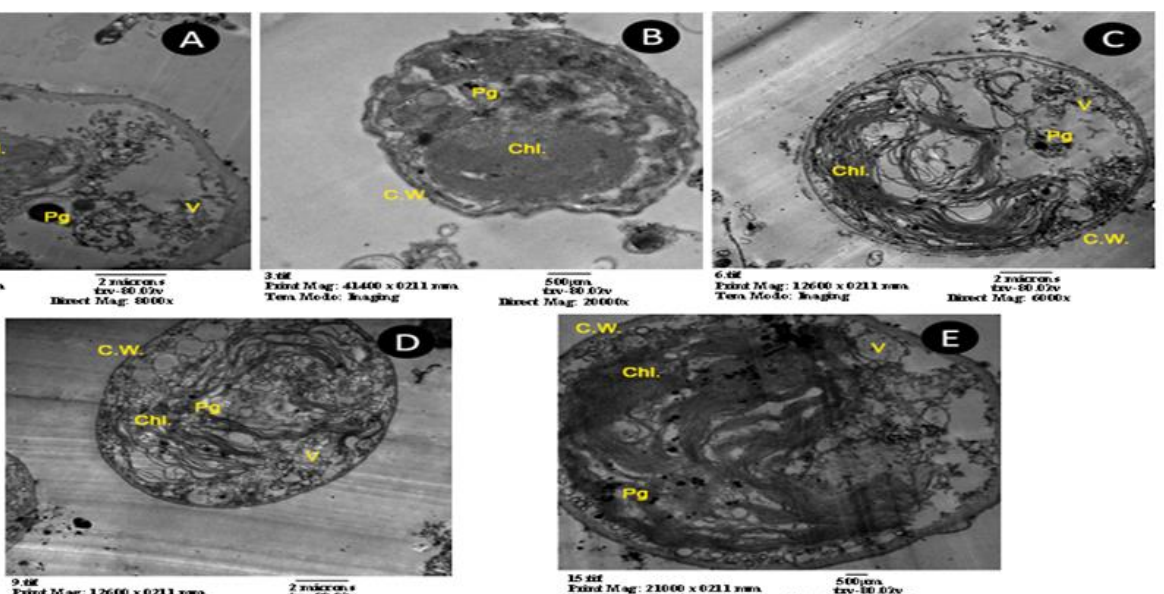

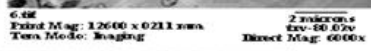
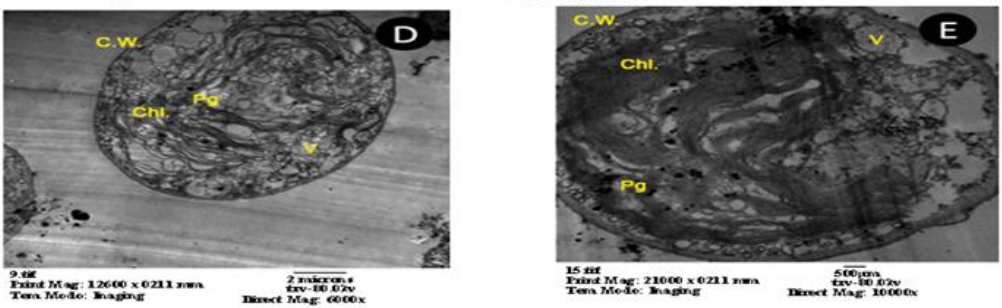

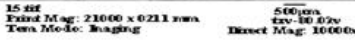

Figure (4 A-E): Ultrastructure of Chlorella vulgaris Treated with (75\%) Sewage Concentration Abbreviations: Chl.: Chloroplast; C.W.: Cell wall; Pg: Polyphosphate granules; V: Vacuole 


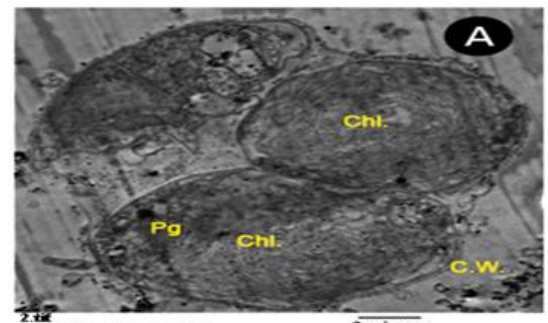

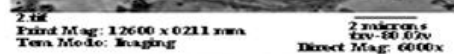
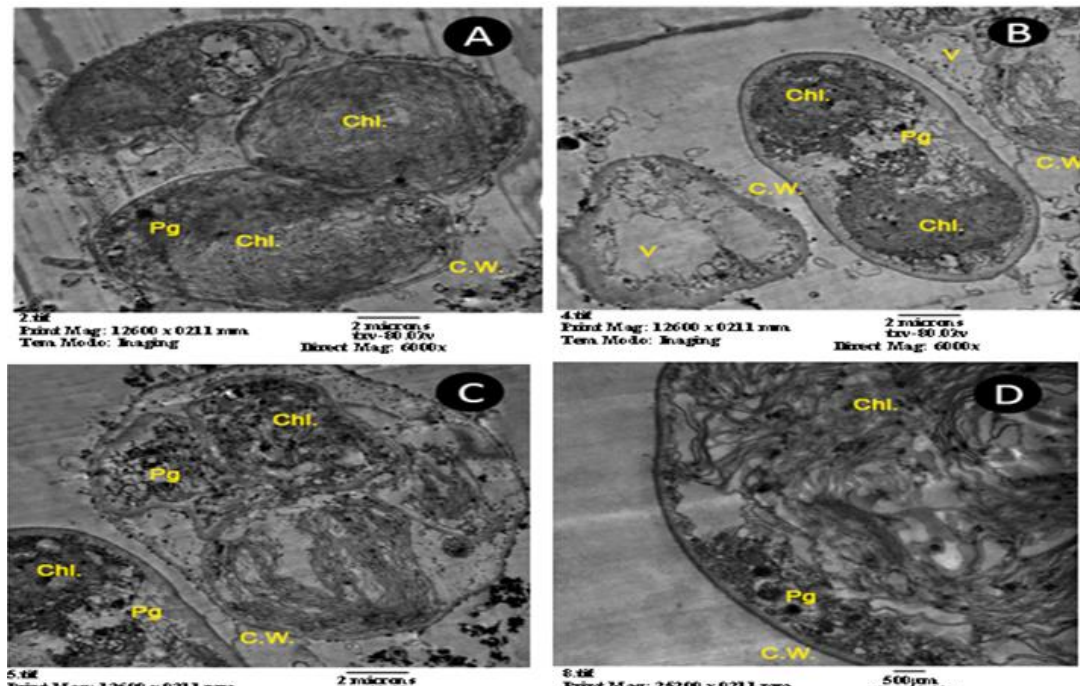

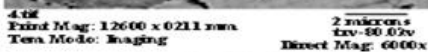
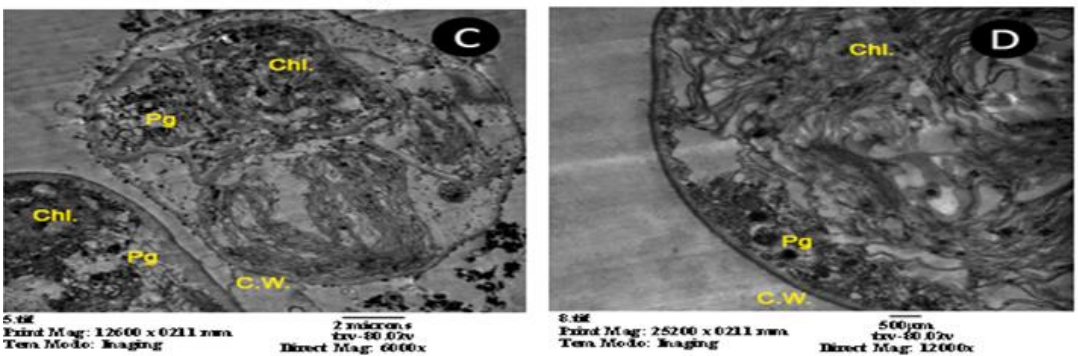

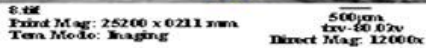

Figure (5 A-D): Ultrastructure of Chlorella vulgaris Treated with (100\%) Sewage Concentration Abbreviations: Chl.: Chloroplast; C.W.: Cell wall; Pg: Polyphosphate granules; V: Vacuole
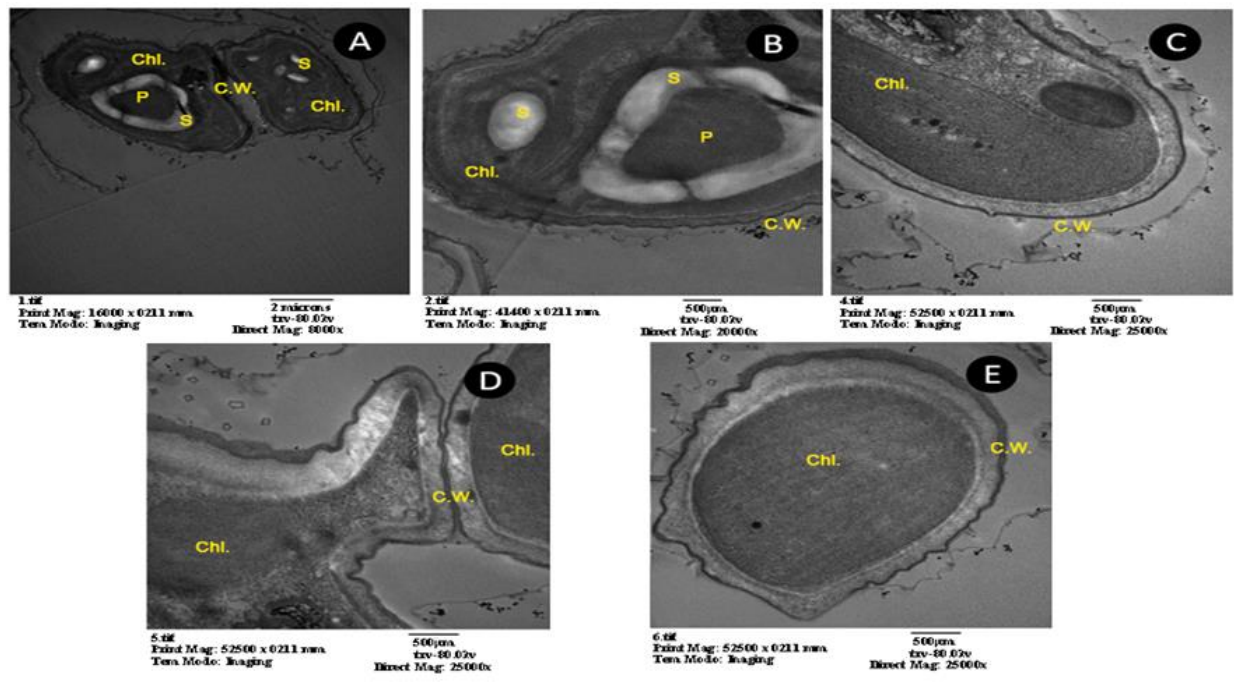

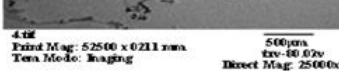

Figure (6 A-E): Ultrastructure of Scenedesmus quadricauda at Control Condition Abbreviations: Chl.: Chloroplast; C.W.: Cell wall; P: Pyrenoid; S: Starch 

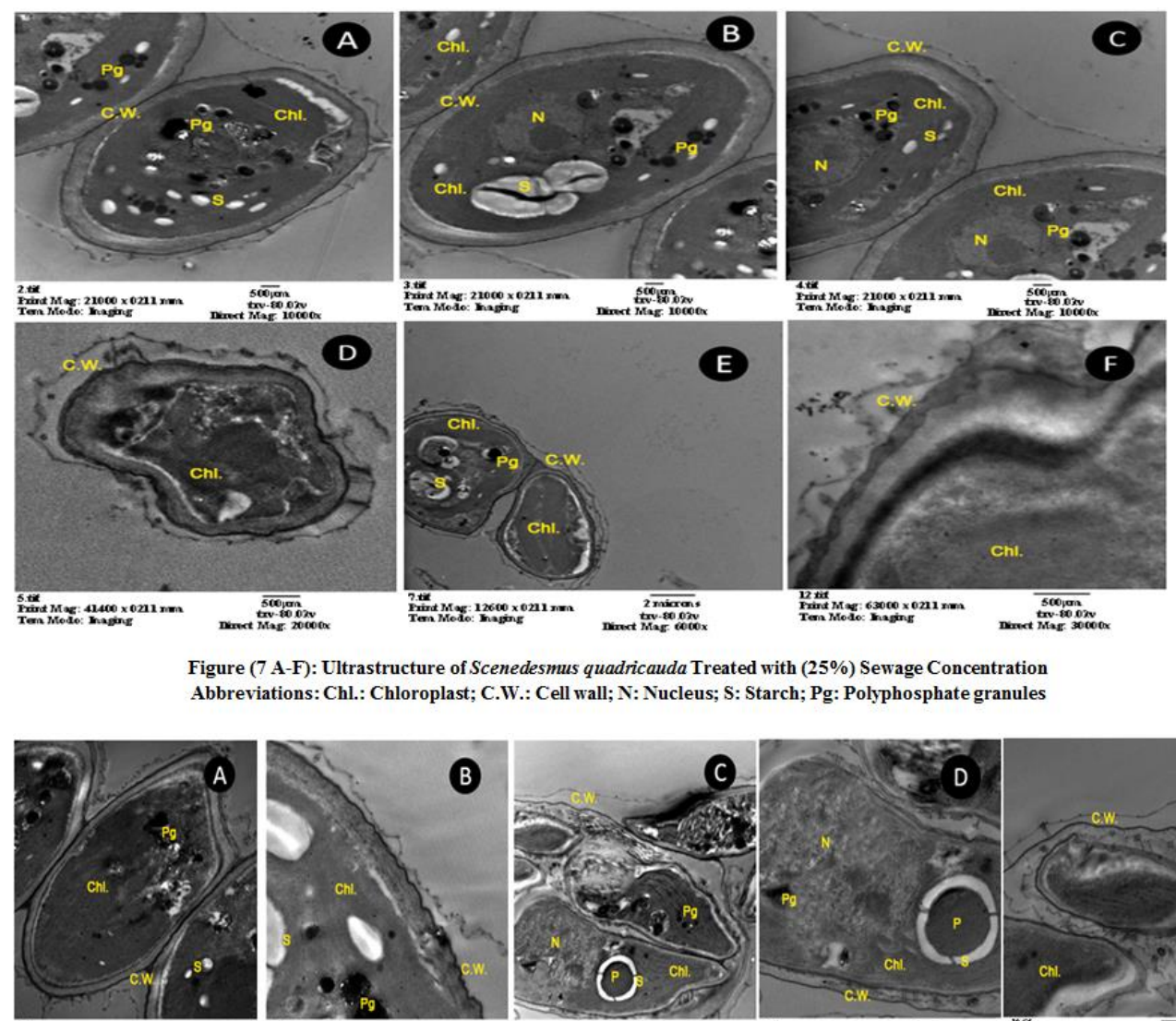

Figure (7 A-F): Ultrastructure of Scenedesmus quadricauda Treated with (25\%) Sewage Concentration Abbreviations: Chl.: Chloroplast; C.W.: Cell wall; N: Nucleus; S: Starch; Pg: Polyphosphate granules
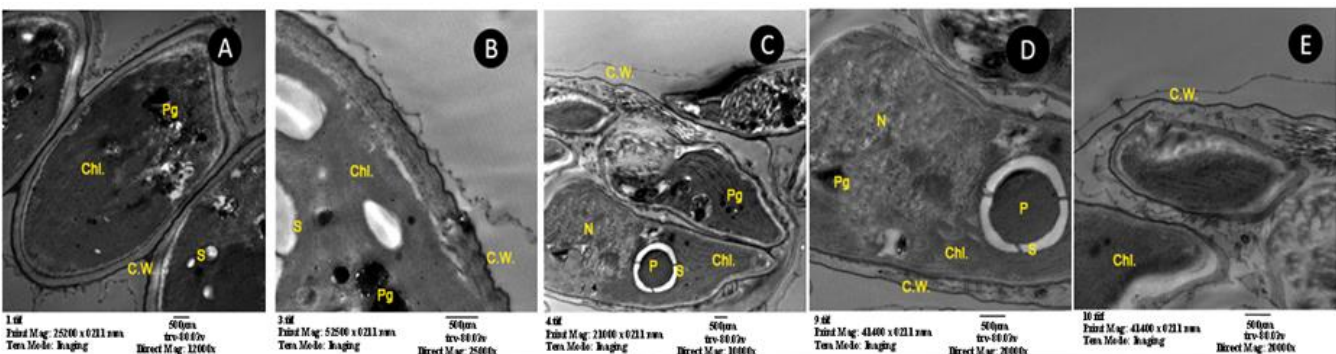

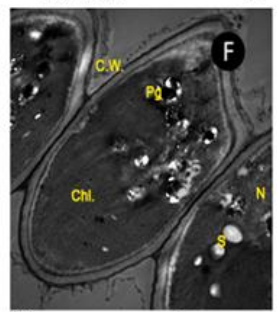

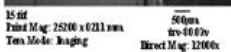

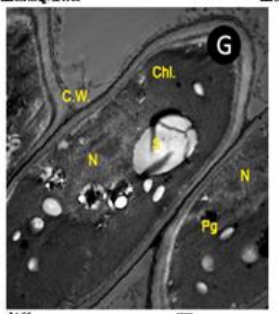

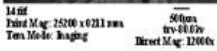

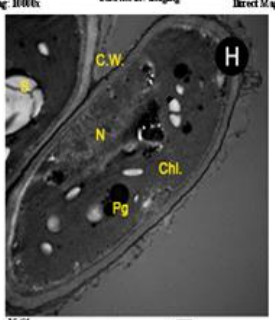

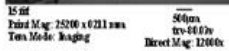

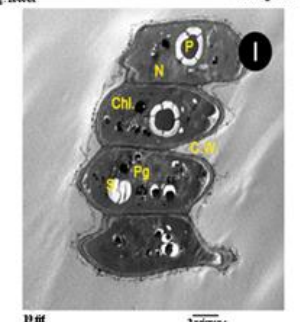

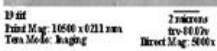

(8 A-1): Ultrastructure of Scenedesmusquadicauda Treated with (50\%) Sewage Concentration Abbreviations: Chl.: Chloroplast; C.W.: Cell wall; P: Pyrenoid; S: Starch; Pg: Polyphosphate granules; N: Nucleus 

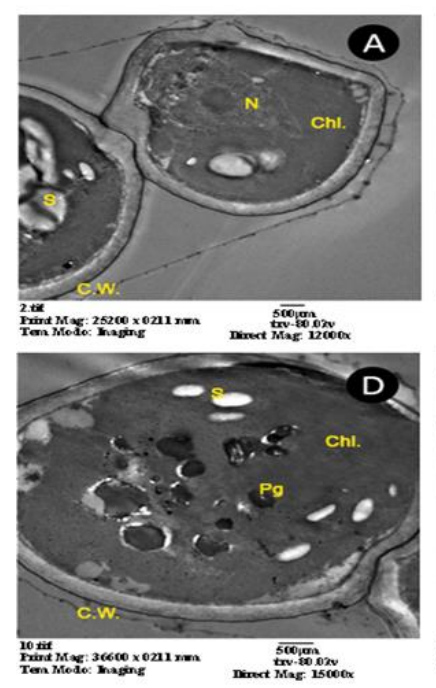
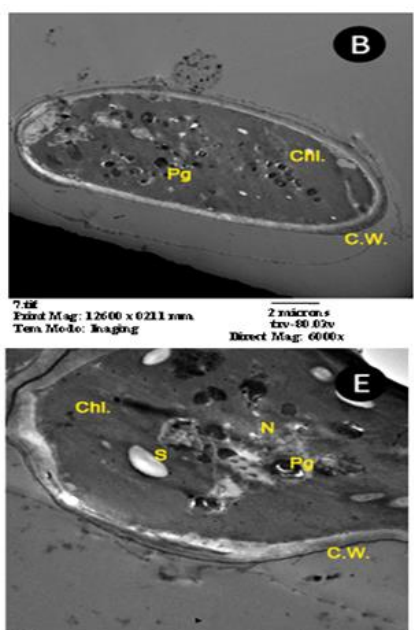

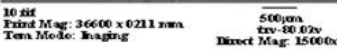

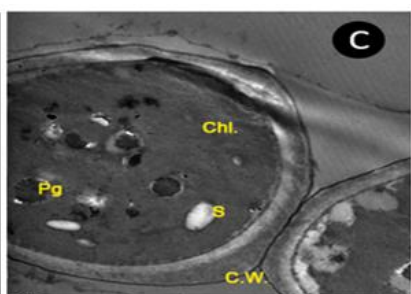

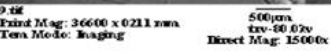

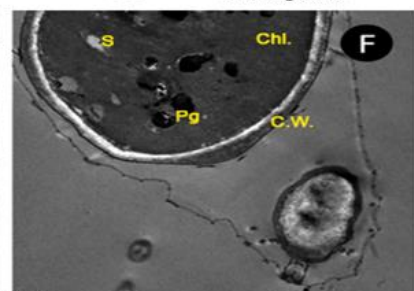

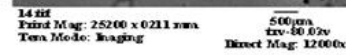

Figure (9 A-F): Ultrastructure of Scenedesmus quadricauda Treated with (75\%) Sewage Concentration Abbreviations: Chl.: Chloroplast; C.W.: Cell wall; S: Starch; Pg: Polyphosphate granules; N: Nucleus

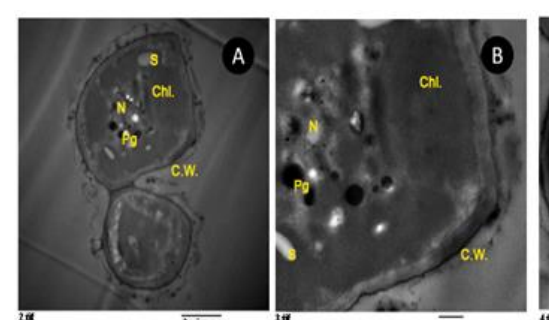

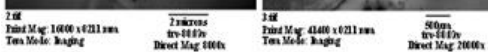

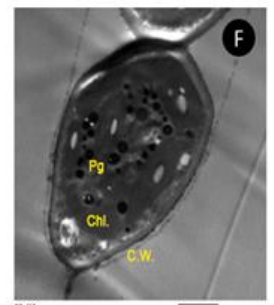

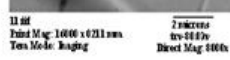

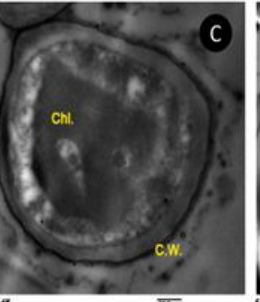

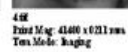

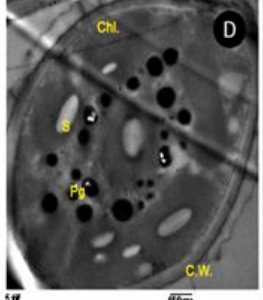

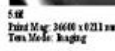

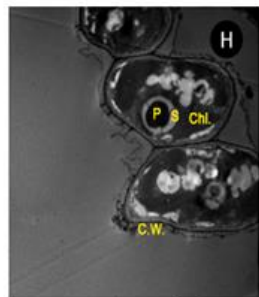

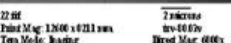

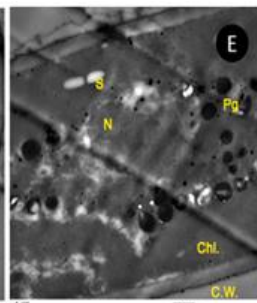

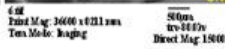

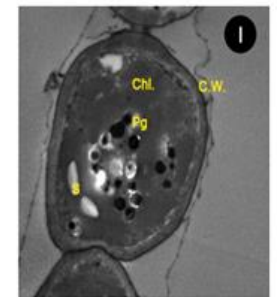

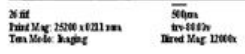

Figure (10 A-I): Ultrastructure of Scenedesmus quadricauda Treated with (100\%) Sewage Concentration Abbreviations: Chl.: Chloroplast; C.W.: Cell wall; P: Pyrenoid; S: Starch; Pg: Polyphosphate granules; N: Nucleus 


\section{References}

Abdel Latef, A.A. and Sallam, M.M. (2015). Changes in growth and some biochemical parameters of maize plants irrigated with sewage water. Austin J. Plant Biol., 1(1):1004-1008.

Afkar, E.; Ababna,H.;Fathi, A.A. (2010). Toxicological Response of The Green Alga Chlorella vulgais to Some Heavy Metals. American J. of Environ. Sci. 6(3):230-237

Aguilera, A. and Amils, R. (2005). Tolerance to cadmium in Chlamydomonas sp. (Chlorophyta) strains isolated from an extreme acidic environment, the Tinto River (SW, Spain). Aquat.Toxicol.,75:316-329.

Akram, M. ; Asif, H. ; Uzair, M. ; Akhtar, N. ; Madni, A. ; Shah, S.M.A. ; UI Hasan, Z. and Ullah A. (2011). Amino acids: A review article. J. Med. Plants Res., 5: 3997-4000.

Anbalagan, R.; Sivakami, R. (2018). Bioaccumulation of Heavy Metals in Water and Algae of Mukkombu in the River Cauvery System, Tiruchirappalli District, Tamil Nadu, India. Int. J. Curr. Microbiol. App. Sci., 7(1): 1067-1072.

Arya, S.K. ;Khalique, S. and Roy, B.K. (2008). Glutathione and cysteine biosynthesis in two varieties of Abelmoschuses culentus in response to mine spoil. J. Environ. Biol., 29(1):93-99.

Azooz, M.M.; Abou-Elhamd, M.F. and Al-Fredan, M.A. (2012). Biphasic effect of copper on growth, proline, lipid peroxidation and antioxidant enzyme activities of wheat (Triticum aestivumcv. Hasaawi) at early growing stage. Austr. J. Crop Sci., 4:688-694.

Bailey, J.L. (1967). Techniques in Protein Chemistry. Elsevier Publishing Co., London, UK.

Basile, A. ; Sorbo, S. ; Bassi, P. ; Napolitano, E. ; Cogoni, A.E. and Cobianchi, C.R. (2008). Effects of heavy metals on protonemal development and ultrastructure in populations of the moss Funaria hygrometrica Hedw.(Bryophyta) from a mine and an unpolluted site. Fresen. Environ. Bull., 17:1956-1963. 
Basile, A. ;Sorbo, S. ; Pisani, T. ; palio, L. ; Munzi, S. and loppi, S. (2012). Bioaccumulation and ultrastructural effects of $\mathrm{Cd}, \mathrm{Cu}, \mathrm{Pb}$ and $\mathrm{Zn}$ in the moss Scorpiurus mcircinatum (Brid). Fleisch and Loeskeenviron .pollut,. 166 : 208-211.

Chekroun, K.B. and Baghour, M. (2003). The role of algae in phytoremediation of heavy metals: A review. J. Mater. Environ. Sci., 4(6): 873-880.

Chekroun, K.B. and Baghour, M. (2003). The role of algae in phytoremediation of heavy metals: A review. J Mater Environ Sci.4(6): 873-880.

Colico, G.; Mecarozzi, P. and Phillippis, D.R. (2010). Treatment of $\mathrm{Cr}(\mathrm{VI})$ containing wastewaters with Exo polysaccharide producing cyanobacteria in pilot flow through batch systems. Applied Microbiol.Biotechnol.., 87: 1953-1961.

Crang, R.E. and Jensen, T.E. (1975). Incorporation of titanium in polyphosphate bodies of anacystisnidulans. J. Cell Biol., 67:80.

Cuin, T.A. and Shabala, S. (2007). Amino acids regulate salinity induced potassium efflux in barley root epidermis. Planta., 225: 753-761.

De Philippis, R. and Micheletti, E. (2009). Heavy metal removal with exopolysaccharide-producing cyanobacteria. In: Heavy Metals in the Environment (eds L.K. Wang, J.P. Chen, Y.- T. Hung and N.K. Shammas). pp. 89-122. CRC Press, Boca Raton, FL.

Dwivedi, S. (2012). Bioremediation of heavy metals by algae: Current and future perspective. J. Adv. Lab. Res. Biol.,3(3): 195-199.

El-Sheekh, M.M. ; El-Naggar, A.H. ; Osman, M.E.H. and El-Mazaly, E. (2003). Effect of Cobalt on growth, pigments and the photosynthetic electron transport in Monoraphid iumminutum and Nitzchia perminuta. Braz. J. Plant Physiol., 15: 159-166.

Fathi, A.A. ;Zaki, F.T. and Ibraheim, H.A. (2005). Response of tolerant and wild type strains of Chlorella vulgaris to Copper with special references to Copper uptake system. Protist., 4:73-78. 
Gasic, K. and Korban, S.S. (2006).Heavy metal stress. In: Physiology and Molecular Biology of Stress Tolerance in Plants (eds K.V. Madhava Rao, A.S. Raghavendra\& K. Janardhan Reddy), pp. 219-254.

Gupta, V.K. and Rastogi, A. (2008). Biosorption of lead from aqueous solutions by green algae Spirogyra species: kinetics and equilibrium studies. $J$. Hazard Mat., 152:407-414.

Hall J.L. (2002).Cellular mechanisms for heavy metal detoxification and tolerance. J. of Experimen. Bot., 53(366):1-11.

Hassinen, V.H. ;Tervahauta, A.I. ; Schat, H. and Karenlampi, S.O. (2011). Plant metallothioneins - metal chelators with ROS scavenging activity? [review article]. Plant Biol., 13: 225-232.

Heng, L.Y. ;Jusoh, K. ; Mui ling, H. and Idris, M. (2004). Toxicity of single and combinations of lead and cadmium to the cyanobacteria Anabaena flos-aquae. Bull. Environ. Contam.Toxicol.,72:373-379.

Hirata, K.; Tsuji, N. and Miyamoto, M. (2005). Biosynthetic regulation of phytochelatins, heavy metal-binding peptides. J. Biosci. Bioeng.,100(6): 593-599.

Homer, F.A. ; Reeves, R.D. and Brooks, R.R. (1997). The possible involvement of amino acids in nickel chelation in some nickel accumulating plants. Curr. Top. Phytochem., 14:31-33.

Hu, S. ; Lau, K.W.K. and Wu, M. (2004). Cadmium sequestration in Chlamydomona sreinhardtii. Plant Sci., 161: 987-996.

Islam, E. ; Liu, D. ; Yang, X. ; Jin, X. ; Mahmoood , Q. ; Tian, S. and Li, H. (2008). Effect of $\mathrm{Pb}$ toxicity on leaf growth, physiology and ultrastructure in the two ecotypes of Elsholtzia orgyi. J. Hazard. Mater,154 (1-3):914 926.

Joshi, V.; Joung, J.G.; Fei Z. and Jander, G. (2010). Inter dependence of threoinine, methionine and isoleucine metabolism in plants: accumulation and transcriptional regulation under abiotic stress. Amino acids, 39(4):933-947. 
Kahoko, N. ; Yoko. Y. ; Isao, U. and Noriko, T. (2003). Ultrastructure changes in Chlamydomonas acidophila (Chlorophyta) induced by heavy metals and polyphosphate metabolism. FEMS Microbiol. Ecol.,44: 253 - 259.

Kasim, W.A. ;Abokassem, E.M. ; Ragab, G.A. and sewelam, N.A. (2014). Alleviation of lead stress toxicity in Vigna unguiculagta by salicypic acid Egypt. J. Exp. Biol. (Bot.).,10 (1) :37- 44.

Lamaia, C. ;Kruatrachuea, M. ; Pokethitiyooka, P. ; Upathamb, E.S. and Soonthornsarathoola, V. (2005). Toxicity and Accumulation of Lead and Cadmium in the Filamentous Green Alga Cladophora fracta (O.F. Muller ex Vahl) Kutzing: a laboratory study. Sci. Asia., 31: 121-127.

Levy, J.L. ; Angel, B.M. ; Stauber, J.L. ; Poon, W.L. ; Simpson, S.L. ; Cheng, S.H. and Jolly, D.F. (2008). Uptake and internalization of copper by three marine microalgae: comparison of copper-sensitive and coppertolerant species. Aquat. Toxicol., 89: 82-93.

Lim, S.; Chu, W. and Phang, S. (2010).Use of Chlorella vulgaris for bioremediation of textile wastewater. J. Bioresour. Technol., 101:73147322.

Macfie, S.M. ;Tarmohamed, Y. and Welbourn P. M. (1994). Effects of Cd, Co, $\mathrm{Cu}$ and $\mathrm{Ni}$ on growth of the green alga Chlamydomonas reinhardtii: The influence of the cell wall and pH. Arch. Environ. Contam.Toxicol.,27: 454-458.

Miao, A.J. and Wang, W.X. (2006). Cadmium toxicity to two marine phytoplankton under different nutrient conditions. Aquat.Toxicol.,78:11426.

Miflin, B.J. and Habash, D.Z. (2002). The role of glutamine synthetase and glutamate dehydrogenase in nitrogen assimilation and possibilities for improvement in the nitrogen utilization of crops. J. Exp. Bot., 53(370):970-987.

Nacorda, J.O. ; Martinez-Goss, M.R. ; Torreta, N.K. and Merca, F.E. (2007). Metal resistance and removal by two strains of the green alga, Chlorella vulgaris Beijerinck, isolated from Laguna de Bay, Philippines. J. Appl. Phycol.,19:701-710. 
Naja, G. and Volesky, B. (2011).The mechanism of metal cation and anion biosorption. In: Microbial Biosorption of Metals (eds P. Kotrba, M. Mackova and T. Macek), Springer, Dordrecht. pp. 19-58.

Nishikawa, K. ;Yamakoshi, Y. ; Uemura, I. and Tominaga, N. (2003).Ultrastructural changes in Chlamydomonas acidophila induced by heavy metals and polyphosphate metabolism. FEMS.Microbiol.Ecolo.,44(2): 253-529.

Muhammad, B.; Tahir, R.; Juan, E.; Ali, R.; Faran, N.; and Hafiz,I. (2018). Biosorption: An Interplay between Marine Algae and Potentially Toxic Elements-A Review. Mar. Drugs., 16( 65):1-16.

Omar, H.H. (2002). Bioremoval of Zinc ions by Scenedesmus obliquus and Scenedesmus quadricauda and its effect on growth and metabolism. Int. Biodeteriorat. Biodegrad.,50:95-100

Osman, M.E.H. ; El-Naggar, A.H. ; El-Sheekh, M.M. and El-Mazally, E. (2004).Differential effects of $\mathrm{Co}^{2+}$ and $\mathrm{Ni}^{2+}$ on protein metabolism in Scenedesmus oblique and Nitzschia perminuta. Environ. Toxicol.Pharmacol.,16: 169-178.

Pahlavanzadeha, H.; Keshtkarb, A. R.; Safdarib, J. and Abadia, Z. (2010).Biosorption of nickel (II) from aqueous solution by brown algae: Equilibrium, dynamic and thermodynamic studies. J. Hazard. Mat., 175:304-310.

Perales-Vela, H.V.; Peña-Castro, J.M. and Cañizares-Villanueva, R.O. (2006). Heavy metal detoxification in eukaryotic microalgae.Chemos.,64:1-10.

Pérez-Urria, C.E. and García, A.A. (2009).Metabolismosecundario de plantas.Reduca.,2(3):119-145.

Philips, R.; Paperi, R.; Sili, C. and Vincenzini, M. (2003).Assessment of the metal removal capability of two capsulated cyanobacteria, Cyanospiracapsulata and Nostoc PCC7936.J. Appl. Phyco.,15:155-160.

Rachlin, J.W.; Jensen, T.E. and Warkentine, B. (1984).The toxicological response of the alga Anabaena flos-aquae (Cyanophyceae) to cadmium. Arch. Environ. Contam.Toxicol.,13:143-151. 
Rai, V. (2002).Role of amino acids in plant responses to stresses. Biol. Plantarum., 45 (4): 481-487.

Reynolds, N. (1963). The culture of algae and rotifers in the fish food unit of lowest oft. Fisheries Laboratory Technical Report Series No. 13. Ministry of Agriculture FAO.pp.1-6.

Rocchetta, I.; Mazzuc, V.and Carmen, M.R. (2006). Effect of chromium on the fatty acid composition of two strains of Euglena gracili. Environ. Pollut.,141:353-358.

Shanab, S. ; Essa, A. and Shalaby, A. (2012). Bioremoval capacity of three heavy metals by some microalgae species (Egyptian isolates). Plant Signalling and Behaviour, 7(3):1-8.

Sharma, P. and Dubey, R.S. (2005). Lead toxicity in plants. Braz. J. Plant Physiol.,17:35-52.

Stanier, R.Y.; Kunisawa, R.; Mandel, M. and Cohen-Basire, G. (1971).Purification and properties of unicellular blue-green algae (order chroococales). Bacteriol. Rev., 35: 171-205.

Swift, D. T. and Forciniti, D. (1997). Accumulation of lead by Anabaena cylindrica: mathematical modeling and an energy dispersive X-ray study. Biotechnol.Bioeng.,55:408-419.

Tripathi, B.N.I. and Gaur, J.P. (2006). Physiological behavior of Scenedesmussp. during exposure to elevated levels of $\mathrm{Cu}$ and $\mathrm{Zn}$ and after withdrawal of metal stress. Protoplasma.,229: 1-9.

Tuzun, I. ; Bayramoğlu, G. ; Yalçin, E. ; Başaran, G. ; Celik, G. and Arica, M.Y. (2005). Equilibrium and kinetic studies on biosorption of $\mathrm{Hg}(\mathrm{II})$, $\mathrm{Cd}$ (II) and $\mathrm{Pb}$ (II) ions onto microalgae Chlamydomonas reinhardtii. J. Environ. Manage.,77:85-92.

Visviki, J. and Rachlin, J.W. (1994). Acute and chronic exposure of Dunaliella salina and Chlamydomonas bullosa to copper and cadmium: Effects on ultrastructure. Arch. Contam. Toxicol.,26:154-162.

Wong, S.L. ;Nakamoto, J.F. and Wainwright, J.F. (1994). Identification of toxic metals in affected algal cells in assays of wastewaters. J. of Applied Phycol.,6:405-414. 
Wu, G. (2009). Amino acids: metabolism, functions, and nutrition. Amino Acids, 37:1-17.

Wu, G. (2009). Amino acids: metabolism, functions, and nutrition. Amino Acids, 37:1-17.

Xiong, Z.T. ; Liu, C. and Geng, B. (2006). Phytotoxic effects of copper on nitrogen metabolism and plant growth in Brassica pekinensis Rupr. Ecol. Environ. Safety, 64:273-280.

Zhang, J.Y.; Ding, T.D. and Zhang, C.L. (2013). Biosorption and toxicity responses to arsenite (As[III]) in Scenedesmus quadricauda. Chemosphere.,92:1077-1084. 
التأثيرات الناتجة عن استخدام مياه الصرف الصحي علي التركيب الدقيق

Scenedesmus quadricauda و Chlorella vulgaris

$$
\begin{aligned}
& \text { حنان عبد الله سعيد حسان* ، ربيع عبد التواب ثابت شهاب** } \\
& \text { * قسم النبات. كلبه العلوم جامعة الفيوم } \\
& \text { **قسم العلوم البيولوجية و الجيولوجية. كلية التربية جامعة عبن شمس. }
\end{aligned}
$$

أجريت تجارب هذا العمل لدراسة تأثير المعادن الثقيلة من مياه الصرف علي

Chlorella vulgaris

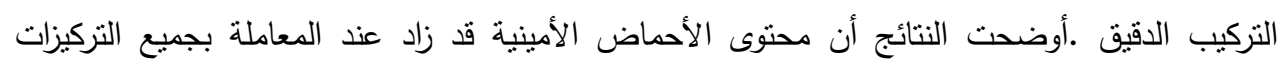

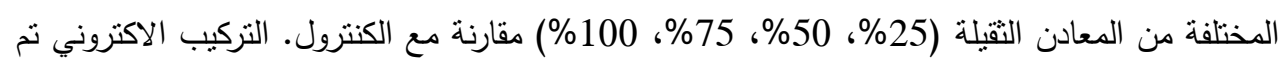

دراستة بالميكروسكوب الإكتروني النافذ وقد لوحظ أن كلا من Chlorella vulgaris و

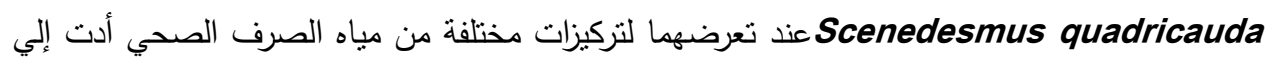

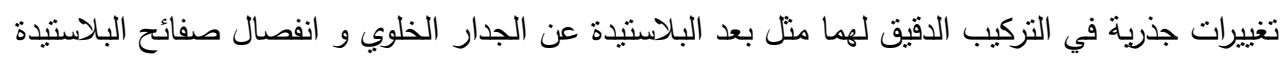

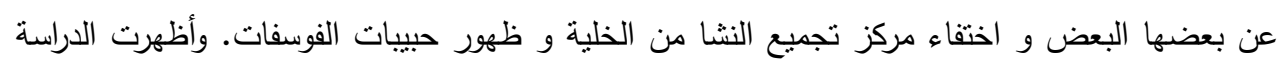

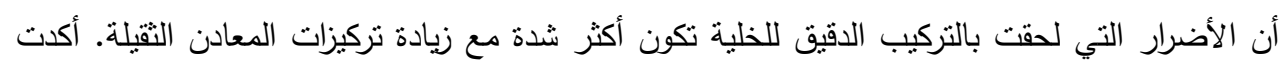

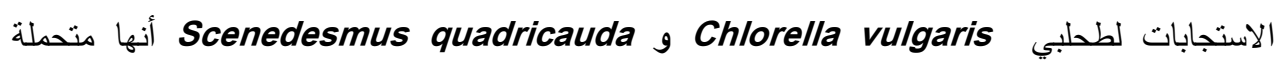

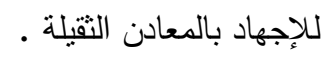

